\title{
Mining management based on inclusive economic approach
}

\author{
Kateryna Kostetska ${ }^{1 *}$, Marius Laurinaitis ${ }^{2}$, Ihor Savenko ${ }^{3}$, Iryna Sedikova ${ }^{3}$, and Serhii Sylenko ${ }^{4}$ \\ ${ }^{1}$ Institute of Market Problems and Economic and Ecological Research NAS of Ukraine, \\ 29 Frantcuzkyi bylvar, 65044 Odesa, Ukraine \\ ${ }^{2}$ Mykolas Romeris University, 20 Ateities St., 08303 Vilnius, Lithuania \\ ${ }^{3}$ Odessa National Academy of Food Technologies, 112 Kanatna St., 65039 Odesa, Ukraine \\ ${ }^{4}$ Zaporizhzhia Polytechnic National University, 64 Zhukovskoho St., 69063 Zaporizhzhia, Ukraine
}

\begin{abstract}
The strategic documents of the state provide for inclusive and green growth aimed at the inclusion of society in the development of the state. It causes the need to highlight the main components of growth and guidelines for their calculation. The international community moved away from using the Gross Domestic Product (GDP) as a measure of economic development, and started measuring growth by calculating the Inclusive Development Index. The study conducted in the article is concentrated on the main directions of the international community development, which focus on assessment of the mineral resource management as one of the levers of increasing the production efficiency and taxes distribution. This article suggests to improve the rent payments for the minerals extraction through a correction factor, since the Tax Code of Ukraine does not take into account the multifunctionality of the territory where these resources are mined. The coefficient is estimated to vary from 1.25 to 2.0 , depending on the polyfunctional characteristics of the mining area. This approach will improve existing methodological recommendations and include such an important area as inclusive green growth in the calculations, as not only the economic indicators of economic activity, but also the environmental feasibility of using the territory where it is carried out will be taken into account.
\end{abstract}

\section{Introduction}

Today the conceptual challenges of green growth relate, first and foremost, to the country's strategic plan for inclusive development and indicators for measuring it. However, the unsolved part of the question remains the indicators by which green growth is measured. Thus, considering the approaches to measurement, there is an ambiguity in the interpretation and definition of key indicators. There is also no single measurement principle that is appropriate for each country, as green growth indicators are generally measured by baselines, ignoring the geographical location or social development of the country. Basically, in the reports a state of the country as a whole is measured, without

\footnotetext{
* Corresponding author: kostetska-k@,ukr.net
} 
highlighting the correction coefficients for depressed regions, or regions with resourceintensive assets.

Management and fiscal control of pollutant enterprises is an unresolved problem with environmental performance today. Thus, environmental pollution indicators demonstrate the neglect of main green growth indicators, namely the number of enterprises for wastewater pollution (34 enterprises), waste disposal (36 enterprises) and air emissions (33 enterprises) [3]. These indicators are at odds with the country's political move towards green growth.

Thus, according to the Ministry of Energy and Environmental Protection of Ukraine, the carbon intensity of GDP in Ukraine is almost twice as high as the global average. Most of the $\mathrm{CO}_{2}$ emissions $-60 \%$ are in the energy sector [1]. According to the Green Investments project [2], in $2018 \$ 1.03$ million was invested in the introduction of hybrid cars, and according to project information this measure will reduce $\mathrm{CO}_{2}$ emissions by 68.85 tons/year. Also, in 2018 the Ministry used funds in the amount of $\$ 22.40$ million on implementation of environmental protection measures, namely: introduction of an economic mechanism for environmental protection, measures for informatization; rational use of water resources; ensuring the rational use and storage of production and household waste. \$7.06 million was used on implementation of environmental programs [23]. Thus, it can be stated that programmatic changes in the public sphere are aimed at environmental sustainability and definition of indicators and methodological basis for their calculation and investment in this field. The Ministry of Economic Development, Trade and Agriculture of Ukraine [3] constantly invests in the development. This is evidenced by the following data: in the first half of 2019, the growth of foreign investments in the economy of Ukraine amounted to $\$ 839.6$ million, and environmental sectors account for $10.1 \%$ of the total development. According to the Sustainable Development Strategy of Ukraine for the period up to 2030 and the directions of green growth in the period from 2014 to 2019 [4], almost \$ 4.4 billion were invested into green renewable energy projects. Thus, during the period of $2015-2019$ the state received the following amount of rent payments for mining [3]:

2015 - \$1681.96 million;

2016 - \$2320.80 million;

2017 - \$1762.88 million;

2018 - \$1638.96 million;

2019 - \$ 1288.80 million.

These statistics indicate that the extraction volume of mining resources does not change, however, there is no clear administrative control and economic levers of regulating the use of these resources.

\section{Problem statement}

Many international documents are devoted to research on green growth indicators. Among the most relevant are the recommendations of the United Nations Environment Program PAGE (2017) [6], which outlines the main indicators for measuring the progress of the green economy and offers an analysis of global achievements by country. The measurement methods proposed in the report are flexible in selecting indicators to compare across countries in any particular aspect of an inclusive green economy. This is extremely important, especially when developing an integrated policy to implement green economy indicators as powerful tools for achieving sustainable development goals, as evidenced by the leadership of the EU's EaP Green (2016) [8], which is devoted to the assessment of the development of the green economy in the following areas: socio-economic, natural assets base, environmental quality of life; economic opportunities and policy instruments. 
Inclusive Green Economy Index is a new benchmark developed by the Asian Development Bank [8], it involves measuring and analysing weak spots in achieving the Millennium Development Goals. The index is designed to reflect key dimensions of economic growth, social justice and environmental sustainability, including climate change adaptation and mitigation. Putting such an index into practice will help to determine the priority, planning and implementation of infrastructure investments in the development of the country and the optimization of financial resources.

Ukrainian scientists are considering the adaptation of the green economy to Ukrainian realities mainly in the sectoral dimension. Studies of Kravchuk [13] focus on aspects of green growth in the agricultural sector to balance the environmental imbalance of rural areas. In work [14-16], researches are devoted to justification of the principles of green growth as industrial for introduction of cleaner production, on the prospects for developing the green economy through the construction of green growth indicators as an alternative model for innovative development in Ukraine.

Virah-Sawmy [17] examines inclusive growth by building a quality business model that will preserve biodiversity in industrial sectors of the economy. In addition to inclusive economic growth, this approach will promote social exclusivity and preserve the health of the population.

The green growth strategy generally envisages the adoption of programmatic documents at the international level and bringing the laws of countries to revitalization at the state level. This orientation requires an inclusive approach. In other words, the strategy requires inclusivity because many environmental issues are global. Political interaction between neighbouring and inland countries is based in particular on the transformation from resource-intensive to more inclusive and socio-oriented.

Authors Khoshnava, Rostami, Zin, Kamyab and Yousefpour [18] connect green growth with development of socio-ecological infrastructure through justification of environmental quality and well-being of the population by economic indicators.

Offor [19] offered the development of green growth to achieve social development in developing countries. The author substantiated that sustainable political management and analysis of economic development indicators will ensure growth of human capital and creation of new jobs [20].

Merino-Saum, Baldi, Gunderson, Oberle [21] suggest to consider natural resources as the main indicator of socio-economic development of the country. It has been argued that the weak link between governance policy and green growth impedes the country's economic sustainability. To improve the methodological recommendations, the authors proposed an analytical model for assessing green growth as an indicator of sustainable development [22].

Purpose of the research is to highlight the main indicators of green growth, suitable for measuring the ecological and economic aspects of development of the country in the field of mineral resource management based on inclusiveness.

\section{Material and methods}

To determine the methodological basis of the article and identify green growth indicators in Ukraine, a scientific abstraction method was used in order to highlight common indicators among those existing in the UN, UNEP, and OECD international programming documents that could serve as baselines for Ukraine. The analysis of international and domestic achievements allows us to consider green growth as a tool for achieving the MDGs based on an inclusive approach. Recent surveys of the Organisation for Economic Cooperation and Development (OECD) regulate green growth through mandatory regulation of accounting and production for resource extraction. However, the prospects for economic 
growth from mining are still not being considered, although this sector should be competitive in an environment of inclusive green growth, as it includes the basic requirements for such growth, such as improving public health, employment and business development, additional tax revenues to the budget. Therefore, it is important to consider green growth as a tool for managing economic activity using mineral resources.

The author summarizes scientific approaches applying the analytical method of comparing the legal and tax obligations of business entities for developing countries that are involved in mining.

\section{Results and discussion}

State development priorities must be consistent with the methodological basis for green growth and sustainable economic management. Green growth based on inclusivity will accelerate economic diversification and the transition from a dominant economy to an economic structure based on industry and modern services. Therefore, it is important to cover the following indicators:

- environmental and resource efficiency of the economy: carbon and energy efficiency;

- earth's natural resources: resource depletion, inexhaustible energy resources, biodiversity;

- indicators of the ecological and social human development, the state of the environment, pollution and threats to human health;

- economic and investment indicators: introduction of the latest technologies and industries, financing of innovations, high-tech development of the state, export-import indicators, international cooperation, inflation;

- social growth indicators: household incomes, demographic burden, education and skills, employment of the population, labour productivity, provision of housing to households, life expectancy, education and skills, etc.

Summarizing the international principles and indicators of inclusivity green growth and the main processes that accompany the full cycle of environmental management, the following classification features of green economy growth can be distinguished.

At first, it is economic priority in accordance with the sustainability growth. It can give priority to certain areas of economic activity. The main one is the location of natural resources and their economic and environmental value. This is especially true of extracting mineral resources and their accounting parameters [32]. In the process of choosing the direction of economic activity it is necessary to take into account not only profit, but also the loss from the extraction or pollution of a natural resource in the territory, where the enterprise is located.

The functional feature of green growth, based on an inclusive approach, highlights what natural resources are more appropriate to use for business. In doing so, the targeted use of certain resources, such as mining, does not prevent from using these resources for another purpose.

The social feature can be characterized by the well-being of people and their inclusion in the process of environmental management, namely the interdependence of business opportunities in environmental management and access to public benefits from natural resources, as well as improving the health of the population from the usage of extracted resources in production.

Legislative feature of inclusive nature management provides "reasonable" fiscal regulation of economic activity according to the value of the resource used. It also provides regulation of public access to the resource potential of the territory, with certain restrictions for business entities in the territory. 


\subsection{Overview of approaches to determining the inclusive green growth development in mineral industry}

It is very important for principles of environmental management to be consistent at all stages of economic activity that involves usage of mineral resources. In the light of the above, we can distinguish the following principles of green growth on the basis of the inclusive approach:

- involvement of the society (public) in economic activities, on the one hand, and the use of the society by its mental capital and professional skills for profit, on the other; participation of the society in making environmentally-friendly decisions to preserve the environment for future generations;

- integration at the local level of the authorities, business and the public on the issues of sustainable mining management and attracting investments for their conservation through the lens of environmental safety of the region;

- redistribution of powers of the authorities on legislative support and fiscal policy of economic activity regulation, with consideration of the environmental advantages of the region $[29,30]$;

- definition of socio-economic and environmental priorities in attraction of investments and innovations in economic activity of the region;

- investing in human capital for the implementation of clean technologies and means of production and the creation of "smart" cities.

The effectiveness of adherence to the principles has to be oriented on the economic and environmental performance of the country. Such policies will accelerate the diversification of the economy and the transition from a dominant economy to an economic structure based on industry and modern services. The methodological approaches to defining green and inclusive country growth have been developed by the World Economic Forum and the Asian Development Bank $[6,8]$, which proposed indicators to measure the level of country development. They include the level of population impoverishment and health, possibility of obtaining education, access to sanitation and income of the population.

If the approach to determining green growth is inclusive, it is advisable to consider how and by what indicators it is measured. Inclusive growth is still calculated using an index approach and is based on 12 indicators grouped into three IDI groups: 1) growth and development; 2) inclusivity; 3 ) equity between generations and sustainability.

The OECD report on Inclusive Growth [8] proposes a more detailed assessment of inclusive growth based on measurement of economic, natural, human and social capital, including three key indicators. Conditionally, indicators can be divided into economic and social indicators of the well-being of the population, indicators by which households are graded by determining their needs and opportunities to obtain them, and purely social indicators that characterize the health of the population.

Specialists of the Asian Development Bank have included green development indicators in the growth index. The index of economic, social and green growth was constructed [6]. This index included 28 growth indicators:

- employment and population ratio: life expectancy at birth, infant mortality rate, access to quality sanitation, access to quality water, access to electricity, Gini coefficient stratification of society by level of poverty, poverty gap, average years of schooling, completion training, a gap in political participation;

- environmental sustainability: rent of natural resources, renewable fresh water resources, water productivity, $\mathrm{CO}_{2}$ air pollution on GDP, primary energy consumption, renewable energy use including climate adaptation and mitigation.

Common feature in the calculation of these indicators is the economic component of the country's development and the level of poverty and household income. The difference is 
that only the Green Growth Index fully includes the environmental indicators, which are very necessary to measure the overall development of the country.

The existing growth measurement indicators do not fully address the important components. Thus, the fiscal component, export-import operations that use the nature of resource raw materials, investments in inclusive processes and technological component of development, the level of science-intensive developments and their patenting are not taken into account at all. The focus on human capital development is more prominent in the OECD-defined Inclusive Growth Index, while the natural resource component is included in the Green Growth Index.

It will be advisable to focus on the review of health-care industries at all stages of resource management, taking into account the aforementioned requirements of inclusive green growth.

\subsection{Assessing green growth in Ukraine in the mining industry on the basis of inclusivity}

An important component of Ukraine's industrial potential is its mining resource base. In the Code of Ukraine on subsoil, mineral resources are the accumulation of minerals in the depths, on the surface of the earth, in sources of water and gases, at the bottom of reservoirs, which are suitable for industrial use in quantity, quality and conditions of occurrence [10].

More detailed examination of the industry that involves usage of mineral resources in Ukraine will be relevant in the conditions of increasing public awareness about the use of mineral resources in their economic activity, technogenic load on the health needs of Ukrainian population, etc.

However, the lack of effective management of Ukraine's subsoil potential has been hindering the sustainable development of business entities across the country and in individual regions for a long time.

Ukraine is rich in its mining potential -8.761 sites, which can make possible the industry development from an economic point [11]. Of particular interest is the use of minerals both economically and in view of the multifunctionality of the territory.

In total, there are not many natural gas, oil and coal production facilities, which are the main industries from the economic point of view (Fig. 1):

Western region - 239 sites;

Eastern region - 385 sites;

Southern region -61 sites.

The figure related to the extraction of minerals is constantly decreasing. Thus, if in 2008 the total extraction amount in Ukraine was 21435 thousand $\mathrm{m}^{3}$ for natural gas, 2172 thousand tons for oil and 900 thousand tons for coal, in 2018 it was 20037 thousand $\mathrm{m}^{3}$ for natural gas, 1515 thousand tons for oil, 645 thousand tons for coal [11]. This situation indicates that economic activity with the use of mineral resources is economically inappropriate or inaccessible to many enterprises.

Therefore, the analytical basis for the inclusive green growth of the use of mineral resources is the assessment of economic activity on the basis of economic indicators of expediency and environmental burden.

There are three types of mineral extraction, taking into account the multifunctionality of the territory [28]:

- anthropogenic detection of the impact of mineral extraction on environmental pollution;

- social aspect determines the economic interdependence of economic activity with the extraction of mineral resources and the general welfare of the population of the region; 
- technological aspect takes into account the interaction of human and natural environment through the "technology" of activities in the field of mining resources. There are two aspects to this assessment: the feasibility of mining entities and the prospect of site engineering.

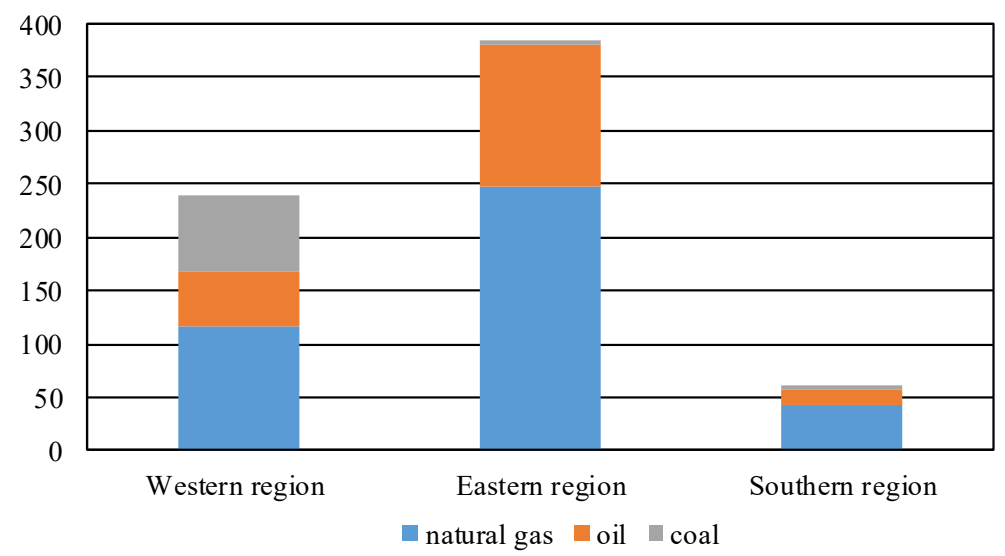

Fig. 1. Balance Sheets of Mineral Resources by Regions [11].

However, at present there is no economic assessment that would cover the entire process of conducting economic activities from the production of mineral resources for their accounting in the process of management, marketing products and administration by the state, which is contrary to international standards of green growth [25]. There are also no calculation parameters for determining the expediency of using and extracting mineral resources, both in terms of economic income from consumption and the environmental component of damaging the resource.

The analytical report [12] on monitoring the landscaping economy during the implementation of the Ukraine-EU Association Agreement lists the indicators for monitoring green changes in industry by the UNEP method, some of them can be applied to the sphere of mining management:

- setting prices for ecosystem services;

- employment - production and management employment (persons, year). Income (\$ or \%) Gini coefficient;

- production efficiency of steady goods and services - gross value added (\$), employment (jobs);

- natural and human capital - value of natural resources (\$), literacy rate (\%).

All these indicators must be justified in the management decisions in the mining industry.

\subsection{Economic feasibility of using mineral resources basing on green growth}

According to the Code of Ukraine on subsoil, payment for mineral resource extraction by business entities is conducted through the provision of natural resources for use or at the expense of payment for the special use of natural resources.

Permit for mining can be obtained only after a competent examination, as well as after the evaluation of the mineral resources themselves in due course. The permit also takes into account the approbation of prospective mining resources, subject to the further approval of certain reserves. In addition, the subsoil user with a specific mining permit at a particular site has the legal right to explore the mineral resources within the territory specified in the permit. 
Let us inspect in more detail the capabilities of subsoil business entities licensed to use subsoil: a qualified geological survey of mineral deposits; pilot - industrial development and competent geological study of specific mineral deposits of national importance;

- professional mining; geological exploration of subsoil, including pilot and industrial development of certain deposits, with further extraction; establishment of geological sites or territories of significant cultural, scientific and well-being importance for Ukraine.

The provision of mining is agreed by the applicant with the following bodies:

- Regional City Councils - for proper use of state resources for the purpose of scientific geological study or competent development of unique mineral deposits, the discovery of which is of national importance. Specific goals that are not related to the extraction of minerals in a particular area are also considered;

- Relevant municipal, district and village councils - competent use of certain subsoil areas that may contain minerals;

- Ministry of Ecology and Natural Resources - for all uses of subsoil.

- State industrial supervision of qualified geological exploration with industrial development and production for non-valuable mining purposes.

The permit granted today is for mining for the period from 5 to 50 years. However, the stipulated time limits continue without economic or environmental audit procedures. Therefore, these rules should be revised.

This situation leads to contradiction between the interests of the state in the rational use of these mineral resources and the private actors. It is common for valuable mineral resources not to be used in accordance with their intended purpose or involved in economic circulation because of the use of other territorially located natural resources, which leads to economic and environmental losses. It should be emphasised that all natural resources as a whole business entities are under different administrative subordination at different levels of government, which leads to their uncontrolled production and use. Therefore, decentralization with the introduction of amendments to the Tax and Administrative Codes of Ukraine is an urgent need.

Therefore, commercial management of mineral resources should provide:

1. Maintaining a cadastre of minerals with determination of their volumes and subsoil entities that are currently using them;

2. Implementation of potential reserves of minerals that can be transferred to commercial circulation;

3. Accounting for all minerals, commercially available and potentially used for commercial use. This feature is very important as there are currently no reserves of potential natural resources, activity licenses and their allocation are issued regardless of the natural resources that can be used in view of their multifunctionality. Inventories reflect information on factual data that neglects the multifunctionality of natural resources and the alternative to their use [26];

4. Mining reserves should reflect all entities, including the entities currently affecting them.

Thus, mining management is the coordinated activity of public authorities on the rational redistribution, use, restoration, protection and regulation of subsoil economic entities, subject to economic and environmental constraints and financial control.

However, nowadays the management of mining resources and subsoil entities is a practical activity of related horizontally different state bodies in the fields of activity and levels of regulation. Mineral management policy should be considered as a sphere of realization of social, economic and environmental interests through management decisions and creation of management system for realization of these interests.

In addition, business entities' tax liabilities include $18 \%$ of income and $20 \%$ of value added tax, which adds to the price of goods and is a nationwide tax [27]. At the same time, 
taking into account the aggregate activity of economic entities in the production and sale of mineral products, we can state that such operations as the survey of new goods, verification at the request of the customer, facilities under construction, reconstruction or operation to comply with the law and conducting custom-made examinations are exempt from taxation. The amount of income received from the sale of mineral resources during the tax period is reduced by the amount of the payer's costs associated with the pre-sales preparation operations, including packaging and bottling.

Another problem is the tax control over the activities of the business entities using mineral resources. Today, tax control is exercising through:

- accounting of taxpayers;

- information and analytical support of the activity of the controlling bodies;

- inspections and reconciliations in accordance with the requirements of the Tax code of Ukraine;

- monitoring of controlled transactions and questioning of taxpayers' officials, authorized persons and/or employees accordingly.

The legislation provides for reporting business entities of conducting economic activity using mineral resources to fiscal bodies on the basis of data, which is specified by the enterprise on its own, with the controlling function of authorities being used only in the circumstances of detected activity violations by business entities, or within the specified time limits of $3-5$ years. However, current practice proves that control over the activity of business entities is almost never being exercised.

Since the permit does not specify the amount of subsoil that the company can remove and during the validity of the permit control of the resource removal is not carried out, the company independently determines the tax base.

In addition, when the control over the activity of economic entities is carried out at the local level and the information on reporting almost immediately goes to the state, the administration of the activity of economic entities using mineral resources is almost impossible.

In light of the above, we note that today the legal base of taxation of economic entities has developed in such a way that there is no reliable data on the use of mineral resources in general. There are currently no methods of calculating tax rates for the introduction of economic entities based on the use of minerals in view of the multifunctionality of the territory, there is practically no control function of the authorities for the production and sale of the resource and products from it, and the entities are managing their activities by their own.

The Tax Code of Ukraine states that tax obligations on rent for the use of subsoil for the tax (reporting) period are calculated by the following formula:

$$
T_{m r}=V_{r t} \cdot U C_{s t} \cdot V R_{m r} \cdot C_{f},
$$

where $T_{m r}$ is tax on the use of mineral resources, UAH; $V_{r t}$ is volume (quantity) of the respective type of subsoil - the extracted subsoil in the tax period (in units of mass or volume); $U C_{s t}$ is unit cost of the corresponding subsoil type, $\mathrm{UAH} ; V R_{m r}$ is value of the rent for the use of mineral resources, UAH; $C_{f}$ is correction coefficient, which basically implies adjustments depending on the extraction of minerals in the waters of the seas or rivers, but does not take into account the multifunctionality of the territory where the extraction takes place.

However, it does not include the polyfunctionality of the territory itself.

The unit cost of the corresponding type of subsoil - the extracted subsoil is determined at the actual selling prices of the respective type of commodity production, or at the estimated cost of the corresponding type of commodity production. 
The specific value of the respective type of subsoil - the extracted subsoil is determined by the actual selling prices of the respective type of commodity production, or by the estimated value of the corresponding type of commodity production. However, if actual selling prices for commodities from oil, non-ferrous metals and ores and gas are published on a monthly basis on the Central Executive Body's website, there is no information on other minerals.

Basically, taxation of the activities of economic entities with the extraction of minerals in developed countries, taking into account the multifunctionality of the territory includes: production tax; tax for the use of the territory where the minerals are extracted; corporate income tax.

Thus, international experience proves that such state control can not only eliminate the excessive burden on natural resources, but also replenish the budget through environmentally friendly economic activity.

Therefore, it is necessary to introduce an additional factor depending on the polyfunctionality of the area in which the minerals and green growth indicators are extracted. This will allow:

- to develop entrepreneurship in this field and create new jobs;

- to follow the minerals in monetary terms;

- replenishment of the budget not only at the expense of an additional rate of use, but also tax revenues from the increase in the number of economic entities in the sector.

Thus, it is necessary to make adjustments to the formula, namely $C_{f}$ is a correction coefficient, which, taking into account the polyfunctionality of the territory, ranges from 1.25 to 2.0 .

Gradation should be established by definition of the polyfunctionality of the territory, namely from the perspective of inclusive green growth, by the following factors:

- Socio-ecological and economic: receiving not only profit from the extraction of minerals, but also human cultural and health development, which can be obtained in this territory and its improved ecological status;

- Ecological and economic: the designation of the territory where the activity is carried out with the extraction of minerals causes indirect damage to the environment and reduces the recreational potential of the territory;

- Economic - when due to the extraction of minerals there is no opportunity for alternative tourism activities.

If a business carries out its activities in the extraction of minerals in an area of health and cultural importance, the extraction rate of minerals should be equal to -2 .

If the business operates in the recreational and tourist territory, then the ratio should be -1.5 . 1.25 ratio should be only on tourist territory.

Prospects for further development of this topic should also be based on: economic accounting of minerals; introduction of green standards for their use; inclusion of requirements for compliance of environmental management with international environmental standards at auctions and tenders for the right to use resources; setting prices for ecosystem services; adapted state control over compliance with international green growth requirements in this field.

The conducted analysis proves the necessity to check such methodological recommendations and update the requirements for calculating the development of the country and its regions.

Guidelines should take into account and be focused on the possibility of calculations not only in indices but also in monetary terms. It is important to take into account the dynamic nature of inclusive processes of green growth in different sectors of the economy, social inclusion [21]. It would be advisable to introduce a coefficient of dynamism that would indicate the current state of development rather than the average. 
In the light of the above, key priority may be to identify further shifts in order to achieve inclusive green growth in the country:

- regulatory measures should reflect the main tools and methodological recommendations;

- fiscal and statistical measures, reflecting the state and dynamics of impact in all areas of growth;

- administrative measures, which should include data from public oversight bodies, reflecting the existing status of all components at national and regional levels;

- analytical measures explaining the changes in the performance of these components;

- interactive and static maps, other data visualization tools and indicators that provide accessibility for understanding and evaluating data and metrics;

- open geospatial data.

It is important to bring the legal and regulatory framework on the legislative level and the possibility of its transformation from state to not only regional, but also to the sectoral level.

\section{Conclusions}

Today, inclusive green growth in the field of mineral resource management must be based on administrative shifts in this area. Economic and environmental indicators of mineral resource usage in economic activity should be determined on the inclusive approach, which is already covered in the current legislation of Ukraine, but is distributed among many normative legal acts.

This study proves that among the major indicators of green growth in the management of minerals, the social factor of social development is neglected the most. Therefore, it is extremely important to improve socio-environmental indicators through economic mechanisms. It is necessary to take into account not only the profit from the mining activities, but also the environmental damage to the territory, given its multifunctionality and social component that can be obtained by the population of the territory, e.g. improving health and cultural development of the population. Authors believe that the achievement of such shifts is possible by improving the rent payments for the extraction of minerals, which will take into account the multifunctionality of the territory. This will help to identify the critical moments of growth to eliminate their disproportionality.

The authors gratefully acknowledge financial support from the Institute of Market Problems and Economic and Ecological Research NAS of Ukraine.

\section{References}

1. Semerak, O. (2018). More than half of Ukraine's greenhouse gas emissions are from the energy sector.

2. Poluyko, V. (2019). Report of the period 1.01.2018 until 31.12.2018.

3. State Statistics Service of Ukraine. (2019). Enviromental of Ukraine.

4. ME of Ukraine. (2019). Excerpt from the State Register of Investment Projects.

5. Kostetska, K., Khumarova, N., Umanska, Y., \& Shmygol, N., \& Koval, V. (2020). Institutional qualities of inclusive environmental management in sustainable economic development. Management Systems in Production Engineering, 28(2), 15-22.

6. UN Environment Programme. (2017). The Green Economy Progress Measurement Framework.

7. Koval, V., Mikhno, I., Hajduga, G. \& Gaska, K. (2019). Economic efficiency of biogas generation from food product waste. E3S Web Conferences, (100), 00039. 
https://dx.doi.org/10.1051/e3sconf/201910000039

8. EaP Green. (2016). Evaluating Green Economy Transformation: A Guide for EU Eastern Partnership Countries.

9. Jha, S., Chand, S. \& Wachirapunyanont, R. (2018). Inclusive Green Growth Index: A New Benchmark for Quality of Growth. Asian Development Bank. Mandaluyong City, Philippines. https://dx.doi.org/10.22617/TCS189570-2

10. Verkhovna Rada of Ukraine. (2019). Code of Ukraine on subsoil.

11. Mineral Resources of Ukraine. (2019). Ukrainian Mineral complex.

12. Potapenko, V., Hlobustov, E., Deineko, L., Gahovich, N., Kyshnirenko, O., \& Ciplicks, O. (2019). Economic greening monitoring.

13. Kovalchuk, S., \& Kravchuk, A. (2019). The Impact of Global Challenges on the Green Transformations of the Agrarian Sector of the Eastern Partnership Countries. Baltic Journal of Economic Studies, 5(1), 87-91 https://dx.doi.org/0.30525/2256-0742/2019-5-1-87-95

14. Petrova, M., Koval, V., Tepavicharova, M., Zerkal, A., Radchenko, A., \& Bondarchuk, N. (2020). The interaction between the human resources motivation and the commitment to the organization. Journal of Security and Sustainability, 9(3), 897-907. https://doi.org/10.9770/jssi.2020.9.3(15)

15. Koval, V., Mikhno, I., Trokhymets, O., Kustrich, L., Vdovenko, N. (2020). Modeling the interaction between environment and the economy considering the impact on ecosystem. E3S Web Conferences, (166), 13002. https://doi.org/10.1051/e3sconf/202016613002

16. Pivnyak, G., Bondarenko, V., \& Kovalevska, I. (Eds.). (2015). New Developments in Mining Engineering 2015. London, United Kingdom: CRC Press, Taylor \& Francis Group. https://doi.org/10.1201/b19901

17. Virah-Sawmy, M. (2015). Growing inclusive business models in the extractive industries: Demonstrating a smart concept to scale up positive social impacts. The extractive industries and Society, 2(4), 676-679. https://doi.org/10.1016/j.exis.2015.07.003

18. Khoshnava, S. M., Rostami, R., Zin, R. M., Kamyab, H., Majid, M. Z. A., Yousefpour, A., \& Mardani, A. (2020). Green efforts to link the economy and infrastructure strategies in the context of sustainable development. Energy, (193), 116759. https://doi.org/10.1016/j.energy.2019.116759

19. Offor, E. (2018). The Future of Inclusive Green Growth and Creation of Decent Jobs in Developing Countries: Attracting Investments for Inclusive Green Growth and Creation of Decent Jobs. SSRN Electronic Journal. https://doi.org/10.2139/ssrn.3100140

20. Yeshchenko, M., Koval, V., \& Tsvirko, O. (2019). Economic policy priorities of the income regulation. Espacios, 40(38), 11.

21. Merino-Saum, A., Baldi, M. G., Gunderson, I., \& Oberle, B. (2018). Articulating natural resources and sustainable development goals through green economy indicators: A systematic analysis. Resources, Conservation and Recycling, (139), 90-103.

22. Bondarenko, V., Kovalevs'ka, I., \& Ganushevych, K. (2014). Progressive Technologies of Coal, Coalbed Methane, and Ores Mining. The Netherlands: CRC Press/Balkema, 521. https://doi.org/10.1201/b17547

23. OECD. (2014). OECD Framework for Inclusive growth.

24. Georgeson, L., \& Maslin, M. (2019). Estimating the scale of the US green economy within the global context. Palgrave Communications, 5(1), 1-12. https://doi.org/10.1057/s41599-019-0329-3

25. Vdovenko, N., Baidala, V., Burlaka, N., \& Diuk, A. (2018). Management mechanism of agrarian economic system: composition, functions and factors of development in Ukraine. Problems and Perspectives in Management, 16(2), 179-189. https://doi.org/10.21511/ppm.16(2).2018.16

26. Yankovyi, O., Goncharov, Yu., Koval, V., \& Lositska, T. (2019). Optimization of the capitallabor ratio on the basis of production functions in the economic model of production. Naukovyi Visnyk Natsionalnoho Hirnychoho Universytetu, (4), 134-140. https://doi.org/10.29202/nvngu/2019-4/18

27. Luchaninova, O., Koval, V., Deforzh, H., Nakonechna, L. \& Golovnia, O. (2019). Formation of communicative competence of future specialists by means of group work. Espacios, 40(41), 11. 
28. Kvasha, S., Pankratova, L., Koval, V., \& Tamošiūnienè, R. (2019). Illicit financial flows in export operations with agricultural products. Intelellectual Economics, 13(2), 195-209.

29. Baklanova, O., Petrova, M., \& Kova,1 V. (2020). Institutional Transmission in Economic Development. Ikonomicheski Izsledvania, 29(1), 68-91.

30. Koval, V., Kovshun, N., Plekhanova, O., Kvitka, S., \& Haran, O. (2019). The role of interactive marketing in agricultural investment attraction. SGEM2019, Ecology, Economics, Education and Legislation. https://doi.org/10.5593/sgem2019/5.3/S21.111

31. Shmygol N., Galtsova O., Solovyov O., Koval V., Arsawan I. (2020). Analysis of country's competitiveness factors based on inter-state rating comparisons. E3S Web Conferences, (153), 03001. https://doi.org//10.1051/e3sconf/202015303001

32. Koval, V., Sribna, Y., Mykolenko, O. \& Vdovenko, N. (2019). Environmental concept of energy security solutions of local communities based on energy logistics. SGEM2019, Ecology, Economics, Education and Legislation. https://doi.org/0.5593/sgem2019/5.3/S21.036 